\title{
Performance Evaluation of Adjustable Elevator for Tractor Drawn Potato Digger
}

\author{
A. Pramod Reddy*, S.C. Moses and Rana Noor Aalam \\ Farm Machinery and Power Engineering, VIAET, SHUATS, Allahabad, U.P., India \\ *Corresponding author
}

\begin{tabular}{|l|}
\hline Ke y w o r d s \\
Potato digger, Tubers, \\
$\begin{array}{l}\text { Digging efficiency, } \\
\text { Harvesting, Bruising } \\
\text { loss, Khurpi }\end{array}$ \\
\hline Article Info \\
\hline $\begin{array}{l}\text { Accepted: } \\
12 \text { October } 2018 \\
\text { Available Online: } \\
10 \text { November } 2018\end{array}$ \\
\hline
\end{tabular}

A B S T R A C T

Potato is the major crop grown in country. It is rich source of carbohydrate, used all over the country. Potato is harvested when it attains the physiologic maturity. Potato harvesting is time consuming operation due to its various activity taken place at the same time. There is different equipment of harvesting the potato from the field. This equipment is tractor operated, animal drawn, or hand operated. Tractor operated potato digger cum elevator is mainly used for digging and exposing potato tubers simultaneously. The digger was found to perform very well under varying soil condition. A potato digger cum elevator was designed and constructed which is capable of digging potato with a minimum of injury working on the principle of digging and elevating the soil and potatoes simultaneously. It reduces $75 \%$ labour and $50 \%$ operating time consumed to conventional method of manual digging with spades, kudali and khurpi. It also results in 4-5\% reduction in harvesting losses. The tractor drawn potato digger elevator was found highly economical, time saving, reducing labour charges with minimum damages. The test results of Potato Digger cum Elevator are actual field capacity is $0.30-040 \mathrm{ha} / \mathrm{h}$, Digging efficiency (\%) is 94-96, Cutting of tubers $(\%)$ is 1.8 , Field efficiency $(\%)$ is 76.5 . It was observed that at a elevator height of $40 \mathrm{~cm}$ the implement is working more efficient rather than at other heights. It was found that there was no damage loss, bruising loss, cutting loss and also there was no bouncing of the tubers on the elevator while digging.

\section{Introduction}

Potato harvesting is one of the most important operations has to be performed preciously to have a good potato production. It has a direct effect on the potato bruising. Bruising has an essential effect on potato marketing. The mechanical bruising could happened when the tractors wheels roll on the potato rows during harvesting. Solanum tuberosum L., potato derived from Spanish language "patata" is an ancient cultivated crop of South America of 16th century when Spaniard arrived and has been considered as one of the oldest tuber crop brought under cultivation in all countries of the world. According to Hawke's potato plant was taken to India by the British missionaries in the late 17th century and to china, a little earlier. Since then, potato is cultivated through the country as a vegetable crop. In India, potato is known by various names in different regions and in various languages, such as Alu in Bengali, potato in English, AlooBatala in Gujarati, Aalu in Hindi, UralaKizangu in 
Malyalam, BilatiAlu in Oria, UruzhaiKilangu in Tamil, Bangaladumpa Aalugadda in Telugu etc. Potato is considered as one of the most important vegetable crops, supplying human with carbohydrate. It is classifies as the first alternative as the grain crops to solve the shortage of food in some countries.

\section{Nutritive value and composition of potato}

Potato is a non-fibrous, non-cereal vegetable crop of both sub-tropical and temperate regions. It occupies the largest area under any single vegetable crop in the world and produces more food content per unit area than cereals in a short time. In some respects, it excels cereals in nutritive value and palatability. Potato tuber chiefly comprises water (75\%-80\%), carbohydrates (16\%-20\%), crude protein $(2.5 \%-3.0 \%)$, fat $(0.1 \%)$ and $1 \%$ minerals like calcium, copper, iron, magnesium, phosphorus, potassium, vitamin B and $\mathrm{C}$.

\section{Area production and yield of potato}

Globally, Potato is one of the main human alimentary resources. It was the sixth alimentary product in the world after sugar cane, maze, rice and paddy, potato is a commonly used vegetable in the country. With production of 40-42 million tonnes, India is the third largest producer of the crop globally. Although India's yield levels are lower than the crop yield per hectare in Germany and Netherlands, they are higher than in china and Russia and the global average, the first three being yield of USA (44.3MT/ha), Netherland (43.6 MT/ha) and Germany (40.0MT/ha). According to the agriculture outlook and situation analysis reports quarterly agricultural outlook report April-June 2012, potato is cultivated throughout the world but it is mainly concentrated in countries like china, France, Germany, India, Netherlands, Spain, Poland and USA. Through the cultivation of potato spread throughout the country, the top 10 potato producing states in the country account for about 97 percent of production covering 90 percent of total crop area. Out of these states, the bulk production is concentrated in Uttar Pradesh, West Bengal and Bihar account for about 78 percent of India's total potato production. UP has a share of 33.12 percent of India's production, followed by west Bengal (31.4) percent and Bihar (13.56). In terms of yield west Bengal tops the list with 32.96 MT per hectare, followed by U.P. with 24.88 MT and Bihar 18.41 MT per hectare. Potato is harvested mainly between October to December and January to April. There is a gap of about four months: May to August when no harvesting is done in any of these states requiring cold storage facilities. Among the common improved potato varieties grown in India, Kufri Chandramukhi (large, Oval, White), kufri Jyoti (large, Oval, white), kufriLalima (medium, round, red) are commonly grown in Uttar Pradesh.

Commercially available tractor mounted elevator digger provide with elliptical agitator is used almost universally by potato growers in harvesting potato. Though this machine reduces the operation time and labor requirement, it deteriorates the quality of potato because of high percentage of damage. Damage is caused primarily due to the constructional parameters, such as rod spacing, jump sprocket for vertical oscillation, web steepness and due to operational parameters, like conveyor to forward steep ratio, peak acceleration and direction of agitator of elevator web. In the elevator digger, elevator web is agitated vertically with the help of elliptical sprocket to separate the potatoes from soil, soil clods and stones if any etc. The elliptical sprocket/ jump sprocket help in creating vertical oscillation of conveyor web which in turn produce vertical oscillation of soil potato mass and potatoes 
after separation, damage in tuber occurs. Because of irregular shape of potato, many of them impact with rods, side walls and solid colds and jump out of the conveyor web inserted windrowing them in a row. Potato jumping and damage become excessive when vertical oscillation is vigor. Extra labor is therefore, required for manual picking. To rectify this problem of bouncing of tubers on the conveyor due to irregular shape, size and structure the adjustable elevator is made at which we can adjust the angle of the elevator to a required distinct. The roller which passes through the dugged surface it makes the irregular surface to level surface were the tubers falls back of the digger on the level surface passing through the conveyor. The project work has been under taken to study the following

\section{Objectives}

To evaluate performance of adjustable elevator for tractor drawn potato digger.

Comparison of different methods of potato harvesting.

\section{Materials and Methods}

The present research "performance evaluation of adjustable elevator for tractor drawn potato digger" was carried out at agronomical conditions of Allahabad (U. P.).

All the trails were carried out at the same time in different plots.

The constructional and functional details of the machine and procedure followed for the field testing and measurements are described below:

Construction \& working principle of machine Field condition and operation of machine Measurement of performance parameters

\section{Working principle}

As the machine moved forward, the $\mathrm{V}$ shaped blades split the ridges and the potatoes were dug out and thrown on the elevator. The disc attached helped in throwing the potatoes on elevator. The elevator further transported these potatoes to the rear end of the elevator. While digging of the potatoes, soil clods came along with these potatoes. These soil clods got broken and dropped due to the spacing provided between the rods in the elevator. The potatoes were easily picked up by the manual labors.

\section{Field condition}

The performance evaluation of the implement was done at karma village, Allahabad (U.P).The shape of the field for trial was rectangular having an area of about $90 \times 20.3 \mathrm{~m}^{2}$. Planting of potatoes in this field was done with planter. The height of the ridges was $15 \mathrm{~cm}$ and the spacing between the rows was $60 \mathrm{~cm}$. Field tests were conducted in the month of February - march 2017. The soil moisture was $11.08 \%$ on dry basis which was adequate for digging operation as the soil did not stick to the potatoes. The variety of potato for which trial was conducted was Badshakopri.

\section{Operation of the machine}

The potato crop was ready for harvesting after 120 days of planting. The harvesting operation was carried in the month of February -march 2017 by potato digger cum elevator machine mounted on M\&M tractor. The test procedures are as follows:

First of all the dimensions of the field where the test was to be conducted were measured and the area was calculated. The length was $90 \mathrm{~m}$ and breadth was $20.3 \mathrm{~m}$. The area of the rectangular field was found to be sq-m. 
The height of the ridges and row to row spacing was measured before harvesting operation. The height of the ridges was $15 \mathrm{~cm}$ and the spacing between the rows was $60 \mathrm{~cm}$.

Three trails were carried out along the length. The depth of cut was fixed it was $15 \mathrm{~cm}$.

Before harvesting operation the fuel tank of the tractor was topped up to the brim.

The amounts of exposed potatoes were picked up manually and their weight was recorded. Later on the potatoes which remained unexposed were dug with the help of khurpi and weighed. From the total amount of potatoes cut and bruised potatoes were separated and weighed properly.

Digging of the potatoes by the implement was done to evaluate the amount of exposed potatoes. Machine was designed as such to avoid covering the potatoes by soil.

Circuitous pattern of machine operation was adopted. In this operation, alternate pair of ridges was dug living beside the adjacent pair. This pattern was adopted to avoid the turning losses in the field.

The height of the elevator was kept at $35,40,45$ and $50 \mathrm{~cm}$ respectively, the trails were done to evaluate the different heights of the elevator, were there is no bouncing of tubers on the elevator due to difference in size, shape. The total time recorded for harvesting operation was recorded with the help of a stop watch and subsequently fuel consumption in liters per hour was calculated by subtracting the amount of fuel left in the tank from the initial amount of fuel taken.

\section{Parameters under study}

Some parameters were taken to evaluate the performance of the digger. There were mainly two types of parameters under which all the factors were considered which are given below:

\section{Independent variable}

Independent variables were those variables which were controlled by the operator.

The independent variables which were taken are given below:

Elevator height: 35, 40, 45 and $50 \mathrm{~cm}$.

Depth of cut: $15 \mathrm{~cm}$

Speed: $3 \mathrm{kmph}$

\section{Dependent variables}

Dependent variables were those variables whose values were dependent on the independent variables. The dependent variables which were taken are given below:

Digging efficiency in percent

Bruising in percent

Damage percentage

Fuel consumption in $1 / \mathrm{h}$

Field capacity

Slippage percentage

\section{Speed}

Assume two points A and B vertically in the center of the field at a distance of 10 meters. When the tractor was in motion and its exhaust pipe came in line with the Point A, the stop watch was started. At the other end again, when exhaust pipe was in line with the point $\mathrm{B}$, the stop watch was stopped. The readings were taken five times, five times in each direction of travel. The readings of the time taken were averaged and the speed of operation was calculated as given below:

Speed $(\mathrm{km} / \mathrm{h})=\frac{\frac{\text { Distance }(\mathrm{m}) \times 60 \times 60}{\operatorname{Time}(\sec ) \times 1000}}{\sin }$ 


\section{Depth of cutting}

The heights of ten ridges were measured randomly before the operation of the machine. The average height of ridges was calculated from these readings. After the operation of the machine, the remaining height was measured at different places. The difference gave the depth of cut of the machine.

(Depth of cut $=$ height of the ridge - height after cut)

\section{Elevator height}

The elevator height is adjusted with the help of adjustable shafts on both sides of the implement, it is based on the bouncing of tubers on the elevator due to variance in size, shape and structure, the height is changed to $35,40,45$ and $50 \mathrm{~cm}$ respectively. The elevator height at which there is no damage, no bruising loss, no bouncing of tubers on the elevator is found.

\section{Measurement of moisture content of soil}

The soil sample was collected from the field and the soil moisture was measured by oven dry method. The soil was dried in the oven and the moisture content after and before was compared. The sample was kept at $105^{\circ} \mathrm{c}$ for $24 \mathrm{~h}$.

\section{Moisture content $\quad(\%)$
$\frac{\text { Intial weight of soil-final weight of soil }}{\text { Intial weight }} \times 100$}

\section{Results and Discussion}

This chapter deals with the discussion of the results of field investigation carried out on the experimental adjustable elevator for tractor drawn potato digger.

The experiment on "Development of adjustable elevator for tractor drawn potato digger" was carried out during the month of February - March, 2017 at karma village, Allahabad. Harvesting of potato with tractor drawn potato digger cum elevator is done in three trails is discussed in the following heads.

\section{General observation}

The potato digger cum elevator is working better at a elevator height of $40 \mathrm{~cm}$. At the elevator height of $40 \mathrm{~cm}$ it was observed that there is no bouncing of tubers on the elevator while digging and the damage loss, bruising loss and cutting loss was less and the digging efficiency is more.

\section{Performance of potato digger cum elevator}

Tractor drawn potato digger cum elevator is suitable for digging and exposing tubers. It saves $75 \%$ labor and operating time and 50\% on cost of operation compared to conventional method of manual digging with spades or by two row potato digger as shown in Table 1 . The forward speed of the digger can vary up to $3 \mathrm{~km} / \mathrm{hr}$. This is highly recommended to the potato grower and to custom hire service.

\section{Moisture content measurements for different plots of the field}

Moisture content has been measured for the different plots of the field by the oven dry method with the help of core cutter and oven. $=$ Three sample of soil for each trail plot were taken for moisture measurement and measured at dry basis. The corresponding values of moisture content \% (db) was $11.79,11.67$ and 9.79 in trail plots I, II, III respectively. The average value of moisture content $\%$ of the field was 11.08 .

From table 1 it was observed that at a elevator height of $40 \mathrm{~cm}$ the implement is working more efficient rather than at other heights. It was found that there was no damage loss, bruising loss, cutting loss and also there was 
no bouncing of the tubers on the elevator while digging.

\section{Cost of operation}

The tractor drawn potato digger elevator was found highly economical, time saving, reducing, labor charges with minimum damages.

The implement cost is approximate Rs.35,000 and its cost of operation is about $1,800 \mathrm{Rs} / \mathrm{ha}$ as compare to $2,400 \mathrm{Rs} / \mathrm{ha}$ by conventional methods and fuel consumption by the potato digger cum elevator is $4.5 \mathrm{Lt} / \mathrm{hr}$. as compare to $5.5 \mathrm{Lt} / \mathrm{hr}$ by use of two row potato digger. The output and input cost calculation, net profit and ratio of output and input cost is shown in the Table 3.

\section{Cost of harvesting by different methods}

The cost of harvesting (Rs/ha) by the tractor drawn potato digger cum elevator (T1) was Rs.1450, by khurpi/kudal (T2) was Rs. 8520 and by tractor drawn two row potato digger (T3) was Rs. 3500.

Tractor drawn potato digger cum elevator is suitable for digging and exposing tubers. It reduces $75 \%$ labor and $50 \%$ operating time compared to conventional method of manual digging with spades and khurpi. Thus we can conclude that harvesting of potato by the potato digger cum elevator is the most economical treatment as shown in Figure 1.

\section{Economics of machine}

With a view of ascertain the economics of harvesting of potato using the potato digging cum elevator, the cost of harvesting under various harvesting method for potatoes was computed. The hourly cost of operation of potato digger cum elevator was lesser than other method of harvesting of potato.
The output input ratio by the tractor drawn potato digger cum elevator (T1) was 1.71 , the khurpi/ kudal (T2) was 1.22 and by the tractor drawn two row potato digger (T3) was 1.28. This we can conclude that the output input ratio was maximum by the tractor drawn potato digger cum elevator as shown in Figure 2. The table 4 indicate that the output input ratio of different harvesting methods were $1.71,1.22$ and 1.24 respectively.

Potato is vegetable crop of both sub-tropical and temperature region of the country. It occupies the largest area under any single vegetable crop in world and produces more food content per unit area than cereals in short span of time. Potato harvesting is time consuming operation due to its various activity taken place at the same time. The harvesting, collection, bagging and transportation to the cold storage/ stores operations are done simultaneously. Traditionally potato is harvested with khurpi/ spade/ kudali and is considered to be labor intensive and time consuming process.

These operations are required about 210 manday per hectare when the crop is harvested manually with spade, khurpi or kudali. The field also become undulated when potato is harvested manually, and require 2-3 weeks for ploughing for next crop. The cost of production of potato become very high because of labor charges and also harvesting. Commercially available tractor mounted potato digger cum elevator are common with farmers having 10 ha or more land. Potato damages like cut, bruise, split etc. are of the order 10-12 percent in elevator diggers. Two pairs of elliptical sprockets that cause separation of potatoes from the soil, soil clods and foreign material, if any are responsible of damage. Therefore, it was felt essential to estimate the extent and type of damage, and soil potato separation by the potato elevator digger (Fig. 3 and 4). 
Table.1 Summary of performance of a tractor drawn potato digger cum elevator

\begin{tabular}{|r|l|c|c|c|}
\hline \multirow{2}{*}{ Sr. No } & \multicolumn{1}{|c|}{ Unit operations } & \multicolumn{3}{|c|}{ Tractor drawn potato digger cum elevator } \\
\cline { 3 - 5 } & & Trail I & Trail II & Trail III \\
\hline $\mathbf{1}$ & Digging efficiency (\%) & 89.28 & 95.77 & 97.4 \\
\hline $\mathbf{2}$ & Damage percent (\%) & 0 & 3.24 & 0 \\
\hline $\mathbf{3}$ & Bruising percent (\%) & 0 & 0 & 0 \\
\hline $\mathbf{4}$ & Depth of digging (cm) & 15 & 15 & 15 \\
\hline $\mathbf{5}$ & Actual field capacity (ha/h) & 0.51 & 0.33 & 0.4 \\
\hline $\mathbf{6}$ & Field efficiency (\%) & 94.44 & 61.11 & 74.07 \\
\hline $\mathbf{7}$ & Slippage percent (\%) & 22.22 & 46.66 & 36.36 \\
\hline $\mathbf{8}$ & Moisture content (db) (\%) & 11.79 & 11.67 & 9.79 \\
\hline
\end{tabular}

Table.2 Test result of the elevator height adjustment of potato digger

\begin{tabular}{|c|c|l|}
$\begin{array}{c}\text { Sr. } \\
\text { No. }\end{array}$ & Elevator height $(\mathrm{cm})$ & \multicolumn{1}{|c}{ Observation } \\
\hline 1. & 35 & Tubers were damaged \\
\hline 2. & 40 & $\begin{array}{l}\text { working was good, there was no bouncing of tubers on the } \\
\text { elevator, no damage, no bruising of tubers }\end{array}$ \\
\hline 3. & $\begin{array}{l}\text { By increase in the height the load increased and slippage was } \\
\text { more }\end{array}$ \\
\hline 4. & $\begin{array}{l}\text { At this height the clods was dugged from more depth, slippage } \\
\text { was more, cutting loss was also more }\end{array}$ \\
\hline
\end{tabular}


Table.3 Test result of tractor drawn potato digger cum elevator

\begin{tabular}{|c|}
\hline Suitable for \\
\hline Actual field capacity \\
\hline Digging efficiency \\
\hline Bruising of tubers \\
\hline Damage \\
\hline Slippage \\
\hline Field efficiency \\
\hline Harvesting cost
\end{tabular}

\begin{tabular}{|c|}
\hline Potato \\
\hline $0.30-0.40 \mathrm{ha} / \mathrm{h}$ \\
$94-96 \%$ \\
$0 \%$ \\
\hline $1.08 \%$ \\
\hline $35.18 \%$ \\
\hline $76.54 \%$ \\
\hline $1450(\mathrm{Rs} / \mathrm{ha})$ \\
\hline
\end{tabular}

Table.4 Summary of output and input cost of the method of potato harvesting

\begin{tabular}{|l|l|l|l|l|l|l|l|l|}
\hline Sr. & $\begin{array}{l}\text { Methods of } \\
\text { harvesting }\end{array}$ & $\begin{array}{l}\text { Cost on } \\
\text { labour } \\
\text { Rs/ha }\end{array}$ & $\begin{array}{l}\text { Machine } \\
\text { charges } \\
\text { Rs/ha }\end{array}$ & $\begin{array}{l}\text { Harvesting } \\
\text { cost } \\
\text { Rs/ha }\end{array}$ & $\begin{array}{l}\text { Total } \\
\text { Input } \\
\text { Cost } \\
\text { Rs/ha }\end{array}$ & $\begin{array}{l}\text { Total } \\
\text { Output } \\
\text { Cost } \\
\text { Rs/ha }\end{array}$ & $\begin{array}{l}\text { Net } \\
\text { Profit } \\
\text { Rs/ha }\end{array}$ & $\begin{array}{l}\text { Output } \\
\text { Input } \\
\text { Ratio }\end{array}$ \\
\hline 1. & $\begin{array}{l}\text { Tractor } \\
\text { drawn } \\
\text { potato } \\
\text { digger cum } \\
\text { elevator } \\
\text { (T1) }\end{array}$ & 600 & 885 & 1485 & 35353 & 60160 & 24825 & 1.71 \\
\hline $\begin{array}{l}\text { Manual } \\
\text { harvesting } \\
\text { by khurpi/ } \\
\text { kudal (T2) }\end{array}$ & 7000 & 1520 & 8520 & 42405 & 51776 & 9371 & 1.22 \\
\hline $\begin{array}{l}\text { Tractor } \\
\text { drawn two } \\
\text { row potato } \\
\text { digger (T3) }\end{array}$ & 1200 & 2300 & 3500 & 37385 & 47680 & 10295 & 1.28 \\
\hline 3.
\end{tabular}


Fig.1 Front view of potato digger cum elevator

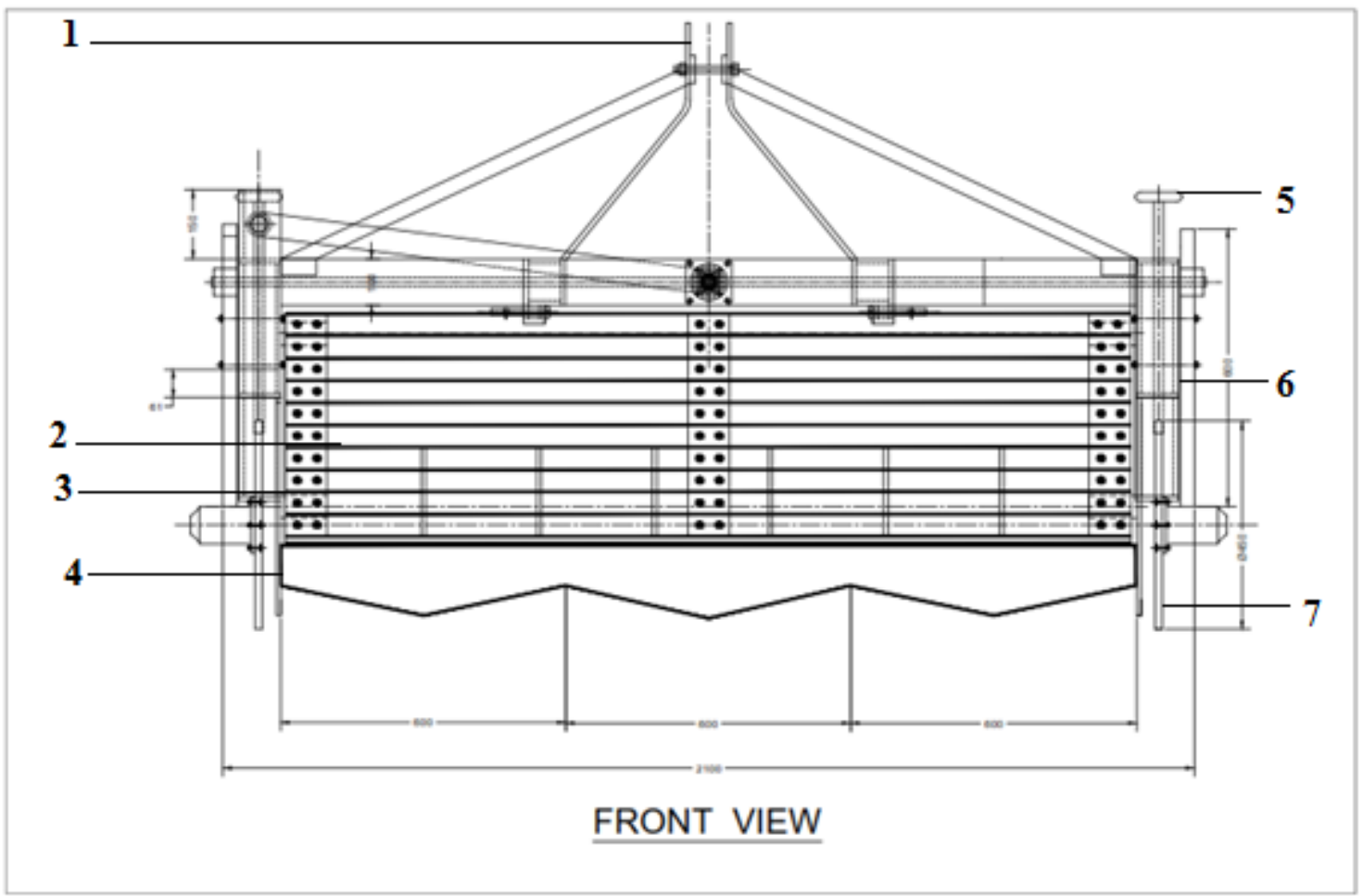

1. Three point linkage 2. Chain elevator 3. Oscillating rod 4. V shaped blade 5. Adjustable elevator shaft 6. V Belt 7. Disc

Fig.2 Working condition of potato digger

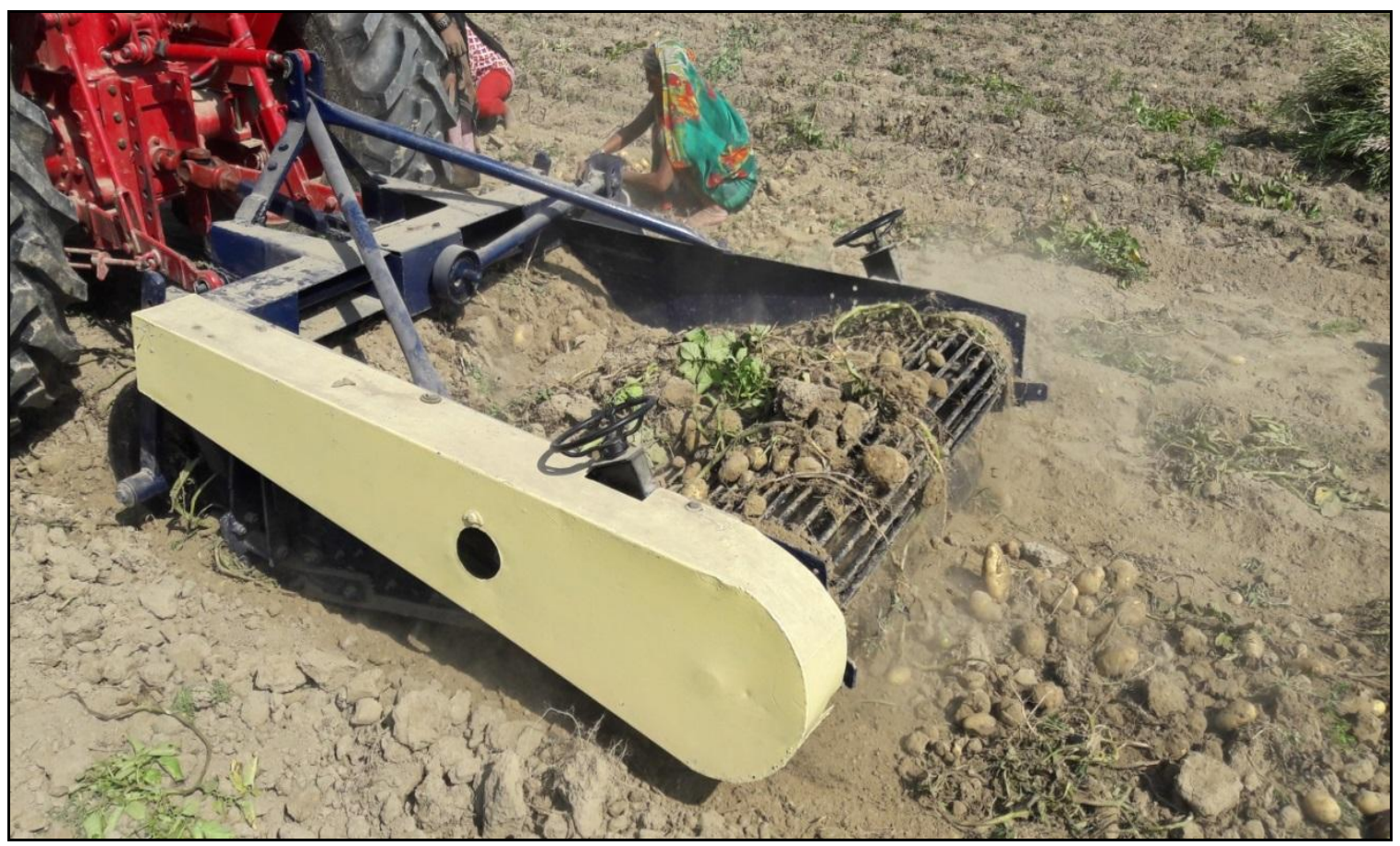


Fig.3 Moisture content (\%) (db)

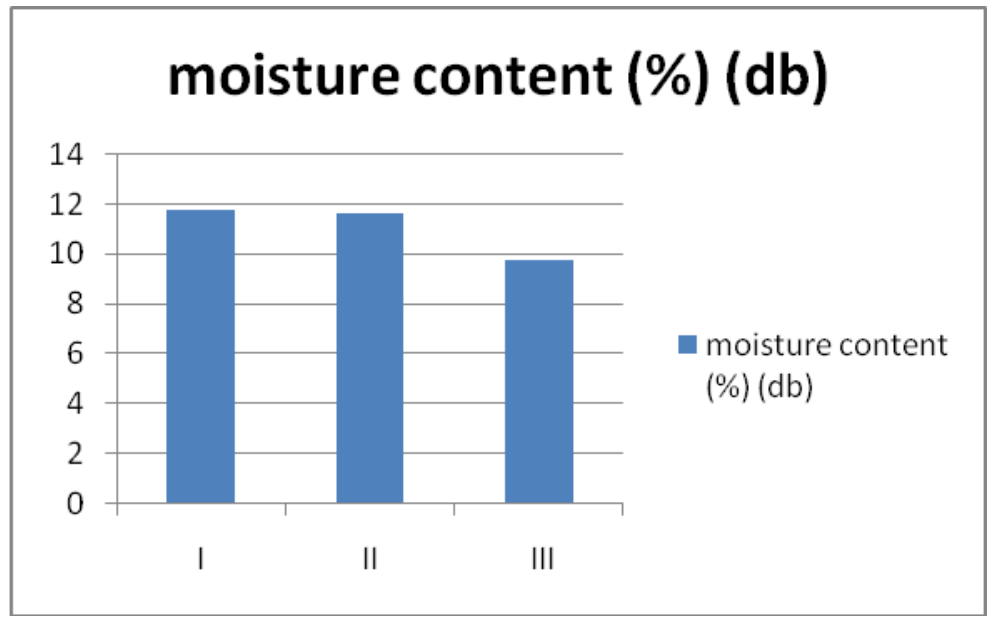

Fig.4 Cost of harvesting of potato (Rs/ha)

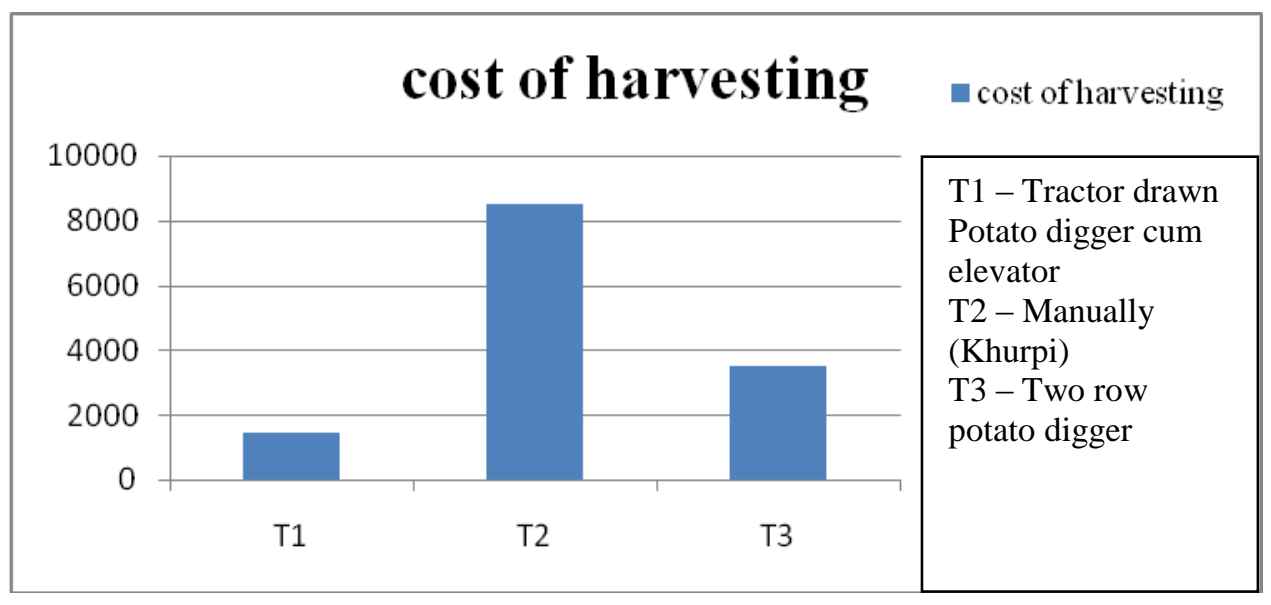

A potato digger cum elevator was designed and constructed which is capable of diggings potato with a minimum injury, working on the principle of digging and elevating the soil and potatoes simultaneously. The digger, which is equipped with hydraulic drive, was found to be very flexible and could accommodate variable condition.

Tractor drawn potato digger is suitable for digging and exposing tubers. It saves 75 percent labor and operating time and 50 percent cost of operation compared to conventional method of manual digging with spades or by cultivators. It also resulted in 4$5 \%$ reduction in harvesting losses.
The following conclusions may be drawn on the field trial of tractor drawn potato digger cum elevator:

The potato digger cum elevator exposed 94$96 \%$ of potatoes in single pass.

The tractor drawn potato digger cum elevator was found highly economical, time saving, reducing labor dependency with minimum damage. This is highly recommended to the potato growers and to the custom high services.

The use of potato digger cum elevator is advantageous for harvesting potatoes in terms 
of cheapness, labor saving, saving in operational time and fuel (diesel) consumption on area basis. The total operational time and diesel consumption per unit area basis by minimum in case it saves 75 percent labor and operating time and 50 percent cost of operation compared to conventional method of manual digging with spades or by cultivators.

It was observed that at a elevator height of $40 \mathrm{~cm}$ the implement is working more efficient rather than at other height. It was found that there was no damage loss, bruising loss, cutting loss and also there was no bouncing of the tubers on the elevator while digging.

The potato damage is about $1-2 \%$ by use of digger cum elevator is comparatively lesser than by use of desi plough and manual digging by spade and khurpi. It results in 4$5 \%$ reduction in harvesting losses.

The percentage of potato digger elevator does not require additional vertical force.

The hourly cost of operation of tractor with tractor drawn potato digger cum elevator was comparatively higher than the other potato harvesting equipment. However the cost of operation on area basis was minimum.

The effective field capacity of machine was $0.40 \mathrm{ha} / \mathrm{hr}$.

\section{References}

Boniface, F. (1971), Development of single row bullock drawn potato digger, unpublished report submitted to AU for B.Sc. Ag. Engg. Degree.

Bruice, A.R. (1950), Effect of potato digger design on tubers injury, Agri. Egg AS.AE, 6 (37). p.p.109.
Grub, E.H. and W.S. Guilford (1912), the potato, Doubleday and Page publications, LONDON, p.p 75-76.

Kang, W. S. and J. L. Handelson 1991, A vibratory, Tow- raw, potato digger transaction of ASAE, vol. 7.

Kathirvel and Manian (2001), A Power tiller Based Potato Digger, AMA, 1 (32), p.p.35-36.

Kumar and Tripathi (2017), performance evaluation of tractor drawn potato digger cum elevator.

Martin, J.W. and E.N. Humphrey (1951), Development of Potato Harvesters, Doubleday and potato publications, LONDON, p.p. 261- 263.

Misenear, G.C. (1985), A tractor mounted potato digger, AMA, 2 (16), p. p.39.

Misener, G.C., D.N. McMillan (1985), A Tractor Mounted Digger for Potatoes, AMA, 2 (6), p.p. 39-40.

MISR J. Ag. Eng. (2006), Development of A Potato Digger 23(2): $292-313$

Singh, C.P. and I.K Garg (1977), Design, Development field valuation of simple Bullock Drawn Potato Digger and Tractor Drawn Potato Digger, Indian Journal of Agri Sciences, 4(2), p.p. 104108.

Singh, S.K and K.L. Verma (1998), Evaluation of the Bullock Drawn Potato Digger, AMA, Farm Machinery Industrial Research Corporation, 1 (20), p.p. 61-62.

Smith, D.W., B. G. Sims and D. H. O' Neill. (1994), Testing and Evaluation of Agricultural Machinery and Equipment. FAO Publishing.

Srivastava, A.K., C. E. Goering and R. P. Rohrbach (1995), Engineering Principles of Agricultural Machines. American Society of Agri. Engg. Pemela Devore Hansen, Editor books \& Journals.

Srivastava, AK (1978), Design and Development of Bullock Drawn Potato 
Digger unpublished project report submitted to A.U. B.SC. Engg., Degree, AAI, Allahabad, p.p.11.
Verma, S. R., R. T. T. Datta and C. P. Gupta (1977), Performance of an experimental potatoes digger with oscillating blades. J. Agri. Engg., 14(30) 99-107.

\section{How to cite this article:}

Pramod Reddy, A., S.C. Moses and Rana Noor Aalam. 2018. Performance Evaluation of Adjustable Elevator for Tractor Drawn Potato Digger. Int.J.Curr.Microbiol.App.Sci. 7(11): 1502-1513. doi: https://doi.org/10.20546/ijcmas.2018.711.173 